\title{
LEX SOCIETATIS VS. LEX FORI CONCURSUS V RAKÚSKOM MEDZINÁRODNOM PRÁVE SÚKROMNOM
}

\author{
DOMINIK KRÁLIK*
}

\begin{abstract}
Lex societatis vs. Lex fori concursus in Austrian Private International Law
From the point of view of the international law of companies, Austria is a traditional continental type of legal culture in which the principle of residence is applied as the decisive criterion for determining the applicable company law. For the law of companies, the provisions of $\S 10$ of the Austrian Private International Law Act are, as regards scope, conceived in the same way as the Czech Section 30 of the Private International Law Act. However, the Austrian lex societatis faces a much greater number of interpretation problems than its Czech "counter-party". This is due to the interference with European Union law, which enshrines for society's very important freedom of establishment. It was on the basis of the freedom of establishment argumentation that the SDEU's extensive case-law was modified, which the Austrian lex societatis largely modified on the basis of the seat.
\end{abstract}

Keywords: Austrian Private International Law; International Business Law; Corporate Law

Kl’účové slová: rakúske medzinárodné právo súkromné; medzinárodné obchodné právo; korporátne právo

DOI: $10.14712 / 23366478.2019 .35$

\section{K AKTUÁLNOSTI TÉMY A ŠTRUKTÚRE PRÍSPEVKU ${ }^{1}$}

V európskom jednotnom trhu s dvadsiatimi ôsmimi právnymi poriadkami by mali zaujímat témy medzinárodného práva súkromného významné miesto v právnej vede. Ďalší dôvod perspektívnosti otázok medzinárodného práva súkromného je daný neustálymi politickými procesmi, ktoré majú za dôsledok rozširovanie či zužovanie medzinárodnej či európskej spolupráce, čo má vo výsledku priame či nepriame dopady do sféry medzinárodného práva súkromného. ${ }^{2}$ Niektoré otázky medzinárodného práva súkromného sa darí, aspoň na úrovni Európskej únie, harmonizovat'. Príkladom

* Autor je interným doktorandom na Katedre obchodného práva Právnickej fakulty Univerzity Karlovy.

1 Tento výstup vznikol s finančnou podporou a v rámci projektu ,Právní regulace transnacionálních podnikatelských seskupeni", GA UK č. 74218, riešeného v rokoch 2018-2019 na Právnickej fakulte Univerzity Karlovej z prostriedkov Grantovej agentúry UK.

2 Aktuálne nie je snád' významnejším dopadom politického rozhodnutia na medzinárodné právo súkromné, než je odchod Spojeného král'ovstva z Európskej únie. 
je jednotná kolízna úprava zmluvných a mimozmluvných záväzkov či kolízna úprava dedičstva. ${ }^{3}$ Hospodársky významné otázky medzinárodné práva spoločností sa však harmonizovat' darí len čiastočne, dovolím si tvrdit', že v niektorých dôležitých otázkach ako napríklad riešenie cezhraničnej podnikatel'skej činnosti, sa prijat' harmonizovanú kolíznu úpravu nedarí. ${ }^{4}$

Z ekonomického hl'adiska predstavuje podnikanie $\mathrm{v}$ niektorom z členských štátov Európskej únie tú výhodu, že je v rámci celej Európskej únie vytvorený jednotný trh. Tento jednotný trh je však rozdelený do 28 jurisdikcií, ktoré by však nemali predstavovat' významné prekážky podnikania v inom členskom štáte. Či je tomu skutočne tak, sa presvedčíme na nasledujúcich riadkoch, a to na príklade rakúskej právnej úpravy.

Všeobecne je možné povedat', že príspevok bude venovaný otázkam rakúskeho medzinárodného práva spoločností. Z historického hl'adiska, kedy sme tvorili s Rakúskom jedno ,súštátie“ by bolo možné očakávat', že rakúska a česká právna úprava medzinárodného práva spoločností bude obdobná. Predpoklad podobnosti rakúskeho a českého medzinárodného práva spoločností zväčšuje skutočnost', že tieto oblasti sú z časti predmetom unifikácie a harmonizácie na európskej úrovni.

Autor sa bude v tomto príspevku tento predpoklad vyvrátit'. Hlavnou hypotézou tohto článku preto je, že rakúske medzinárodného právo spoločností sa od toho českého zásadne líši.

K naplneniu tejto hypotézy, aj vzhl'adom na obmedzený rozsah príspevku, bude uskutočnená analýza základných inštitútov medzinárodného práva spoločností, a to hraničných určovatel'ov. Úvodná čast' príspevku bude venovaná predstaveniu lex societatis $\mathrm{v}$ rakúskom medzinárodnom práve súkromnom. Druhá čast' príspevku najprv predstaví lex fori concursus a následne sa zameria na možný stret lex societatis a lex concursus. Vel'mi špecifický charakter má pritom otázka stretu týchto dvoch hraničných určovatel'ov v prípade medzinárodného koncernu, kde sa autor obmedzí na nestiesnenie hlavných myšlienok.

\section{RAKÚSKE MEDZINÁRODNÉ PRÁVO SPOLOČNOSTÍ}

\subsection{RAKÚSKE POJATIE LEX SOCIETATIS}

Rakúske medzinárodné právo spoločností sa ohraničuje na úpravu osobného štatútu právnickej osoby. Z doktríny sa udáva, že osobný štatút spoločnosti môže byt' vymedzený ako právny poriadok, rozhodný pre posúdenie právnych otázok, spojených s právnickou osobou, tj. právny poriadok, ktorým sa riadi vznik spoločnosti, jej právna povaha, právna spôsobilost' spoločnosti vrátane oprávnení konat' za spoločnost',

\footnotetext{
3 Nariadenie Európskeho parlamentu a Rady (ES) č. 593/2008 zo 17. júna 2008 o rozhodnom práve pre zmluvné záväzky (Rím I), nariadenie Európskeho parlamentu a Rady (ES) č. 864/2007 z 11. júla 2007 o rozhodnom práve pre mimozmluvné záväzky (RÍM II) a Nariadenie Európskeho parlamentu a Rady (EÚ) č. 650/2012 zo 4. júla 2012 o právomoci, rozhodnom práve, uznávaní a výkone rozhodnutí a prijatí a výkone verejných listín v dedičských veciach a o zavedení európskeho osvedčenia o dedičstve.

4 Tu sa majú na mysli hlavne otázky tzv. medzinárodného koncernového práva.
} 
jej vnútorné vzt’ahy, niektoré vonkajšie vzt’ahy, zmena a spravidla aj zánik spoločnosti, prípadne niektoré d'alšie otázky. ${ }^{5}$

Osobný štatút právnickej osoby a obdobných zoskupení zakotvený v § 10 rakúskeho zákona o medzinárodnom práve súkromnom (d’alej len ako „IPRG“海 ${ }^{6}$ rozhoduje o všetkých súkromnoprávnych otázkach právnickej osoby (spoločenský štatút). Z tohto ustanovenia vyplývaj, že rakúske medzinárodné právo spoločnosti je založené na princípu sídla. Osobný štatút právnickej osoby, teda jej lex societatis, je právo skutočného sídla hlavnej správy (nemusí byt' nutne štatutárne sídlo) právneho subjektu, a to pri zohl’adnení prípadného spätného či d’alšieho odkazu (§ 5 IPRG). Nezávisle na alokácii pravidelných schôdzok hlavných zhromaždení, je za sídlo hlavnej správy považované miesto skutočného výkonu obchodného vedenia. ${ }^{7}$ Týmto ustanovením sa rakúske právo spoločností radí medzi tradičné prístupy v kontinentálnej Európe, napríklad spolu s Nemeckom či Talianskom, ked' aplikuje princíp sídla, konkrétne princíp sídla správy spoločnosti.

Rakúsky lex societatis je tak určený miestom, kde sa sústred’uje určitým spôsobom upresnená faktická činnost' spoločnosti. ${ }^{8}$ Jedná sa o miesto na ktorom sa rozhoduje o zásadných rozhodnutiach spoločnosti v rámci obchodného vedenia a kde sa vykonáva správa spoločnosti. Skutočné sídlo ústrednej, teda hlavnej správy spoločnosti je miesto, na ktorom výkonný orgán uvádza zásadné pokyny politiky spoločnosti do denného chodu. ${ }^{9}$ To platí aj pre právnické osoby medzinárodných koncernov, rovnako ako pre dcérske spoločnosti s právnou osobnost'ou.

Podla § 1 ods. 1 IPRG, ak nie je možné zistit' skutočné sídlo, napríklad z dôvodu neexistencie vnútornej štruktúry spoločnosti, aplikuje sa zásada najužšieho spojenia. Pod pojmom právnická osoba alebo iné zoskupenie osôb či majetku, ktoré môžu byt' nositel'mi práv a povinností, sa rozumejú všetky druhy obchodných spoločností, a to bez ohladu na to, či disponujú právnou osobnost'ou (v slovenskej terminológii odpovedá tento pojem právnej subjektivite) alebo nie. Rovnako osobné spoločnosti alebo majetkové zoskupenia s vlastnou právnou osobnost'ou, ako spolky či nadácie, či ranné štádia vzniku spoločnosti a nakoniec aj tieňové spoločnosti (Scheingesellschaften $)^{10}$

5 PAUKNEROVÁ, M. Společnosti v mezinárodním právu soukromém. Praha: Karolinum, 1998, s. 28.

6 Spolkový zákon zo dňa 15. júna 1978 o medzinárodnom práve súkromnom (IPR-Gesetz), číslo 304/1978 rakúskej Zbierky zákonov.

7 Rozhodnutie rakúskeho najvyššieho súdu zo dňa 28. augusta 1997 pod spisovou značkou 3 Ob 93/97s, dostupné na: https://www.ris.bka.gv.at/Dokument.wxe?Abfrage=Justiz\&Dokumentnummer=JJT_19970828 OGH0002_0030OB00093_97S0000_000 [14.1.2019].

8 PAUKNERŌVÁ, M. op. cit. sub 5, s. $\overline{8} 1$.

9 Ide o takzvanú Sandrockovu formulu, viz SANDROCK. O. Die Konkretisierung der Überlagerungstheorie in einigen zentralen Einzelfragen. In: SANDROCK, O. (Hrsg.). Festschrift für Günther Beitzke. Berlin, New York, 1979, s. 669 a 683.

10 VERSCHRAEGEN, B. Internationales Privatrecht. Wien: Manz, 2012, s. 188. S odkazom na rozhodnutie rakúskeho najvyššieho súdu pod spisovou značkou 9 ObA 45/87, rozhodnutie rakúskeho súdu pod spisovou značkou 3 Ob 2029/96 w, rozhodnutie rakúskeho najvyššieho súdu pod spisovou značkou 9 ObA 45/87, rozhodnutie rakúskeho najvyššieho súdu pod spisovou značkou 6 Ob 83/67, Rozhodnutie so spisovou značkou $1 \mathrm{Ob} 537 / 89$ či $2 \mathrm{Ob}$ 238/07 z a rozhodnutia rakúskych súdov pod spisovou značkou 1 Ob 120/00 d, 3 Ob 2029/96 w. 
Podl'a teórie sídla je pre osobný štatút právnickej osoby rozhodné právo štátu, v ktorom má právnická osoba skutočné správne sídlo. Ak premiestni svoje skutočné sídlo do zahraničia, tento osobný štatút sa zákonite musí zmenit'. Teória sídla má tie výhody, že zohl'adňuje miesto skutočnej činnosti právnickej osoby, a tým môže zadostučinit' ochrane veritel'ov, spoločníkov a vôbec hladkosti priebehu transakcií.

Z teórie sídla vypláva, že právnická osoba, ktorá premiestni ústrednú správu zo štátu, kde bola založená, do iného štátu, bude pravdepodobne konfrontovaná so stratou právnej osobnosti, bude musiet' byt' nanovo založená a zároveň sa bude musiet' podriadit' novým, niekedy vel'mi prísnym, pravidlám pre zloženie kapitálu, zachovanie kapitálu, stanovy či pravidlám pre spoluúčast' zamestnancov na rozhodovaní spoločnosti. ${ }^{11}$

Naopak štáty ako napríklad Švajčiarsko, Holandsko, Írsko či Česká republika pre určenie osobného štatútu spoločnosti používajú inkorporačný princíp. Podl’a inkorporačnej zásady je osobným štatútom právnickej osoby právny poriadok, podla ktorého právnická osoba vznikla. Vychádza sa z toho, že tento právny poriadok priznáva určitému organizovanému útvaru právnu osobnost’ a uznáva ju za právnickú osobu. Tento právny poriadok je možné $\mathrm{v}$ praxi zistit' obvykle podl'a toho, $\mathrm{v}$ ktorom štáte je právnická osoba zapísaná do verejných kníh, registrov a podobne. Tento zápis má obvykle konštitutívny účinok a je podmienkou vzniku spoločnosti. ${ }^{12}$ Hovorí sa aj o tzv. štatutárnom sídle právnickej osoby, ktoré odpovedá zapísanému sídlu v spoločenskej zmluve či stanovách právnickej osoby.

V českom medzinárodnom práve spoločností je osobný štatút upravený v ustanovení $\S 30$ zákona o medzinárodnom práve súkromnom, ${ }^{13}$ pričom definíciu sídla nájdeme $\mathrm{v}$ českom občianskom zákonníku. ${ }^{14}$ Napriek tomu, že oba tieto zákony sú účinné od 1. januára 2014, ku skutočnej revolúcii prijatím týchto aktov nedošlo. Aj pred rokom 2014 sa aplikoval inkorporačný princíp. ${ }^{15}$ Dnes to vyplýva z $§ 136$ a $§ 137$ občianskeho zákonníku, ktorý používa pojmu „zapísané sídlo“. Zapísané sídlo v registri odpovedá teda formálnemu pojatiu sídla. Skutočné sídlo môže byt' pritom kdekol'vek, nemusí vôbec korešpondovat's tým, čo je zapísané v obchodnom registri. ${ }^{16}$ Formálne sídlo je preto určujúcim hraničným určovatel’om pre určenie lex societatis spoločnosti podl'a českého medzinárodného práva spoločností.

Napriek tomu, že sa v českom práve uplatňuje princíp formálneho sídla, úplne bez významu nezostáva ani princíp materiálneho sídla. Podl'a $§ 137$ občianskeho zákonníku platí, že sa každý môže dovolat' skutočného sídla právnickej osoby a taktiež platí, že proti tomu, kto sa dovolá sídla zapísaného vo verejnom registri, nemôže právnická osoba namietat', že má skutočné sídlo na inom mieste.

11 Tamtéž, s. 185.

12 PFEIFFER, M. In: KUČERA, Z. - PAUKNEROVÁ, M. - RŮŽIČKA, K. Mezinárodní právo soukromé. Praha: Aleš Čeněk, 2015, s. 251-252.

13 Zákon č. 91/2012 Sb., o mezinárodním právu soukromém.

14 Zákon č. 89/2012 Sb., občanský zákoník.

15 PAUKNEROVÁ, M. - BRODEC. J. In: GERNER-BEUERLE, C. - MUCCIARELLI, F. - SCHUSTER, E. - SIEMS, M. The Private International Law of Companies in Europe. München: C. H. Beck, 2019, s. 308 .

16 Tamtéž, s. 309. 
Nezávisle na skutočnej právnej osobnosti podl'a rakúskeho materiálneho práva sa $\S 10 I P R G$ vzt’ahuje okrem právnických osôb aj na ostatné majetkové súbory, ktoré môžu byt' nositel'mi práv a povinností. Tak sa toto ustanovenie vzt'ahuje na osobné aj kapitálové spoločnosti $(\mathrm{OG}, \mathrm{KG}, \mathrm{AG}, \mathrm{GmbH}$, spolky, ústavy, spoločnosti občianskeho práva, nadácie a fondy). Tak sem spadajú aj začiatočné štádiá vzniku spoločnosti a taktiež tieňové spoločnosti. Svojprávnost' a postavenie majetkovej podstaty patria medzi sporné otázky. Pre tieto otázky by sa mali použit' zvláštne hraničné kritériá, napr. nariadenie o dedičstve, nariadenia o insolvencii, Brusel I bis. ${ }^{17}$ Pobočky podliehajú svojmu vlastnému právnemu poriadku, a to podla ich hypotetického lex societatis. Iný lex societatis bude mat' právnická osoba, ktorej táto pobočka patrí. V medzinárodných koncernoch má vel'ký význam lex societatis dcérskej spoločnosti.

Podl'a ustanovenia $\S 10$ rakúskeho zákona o medzinárodnom práve súkromnom osobný štatút zahrňuje úpravu právnej osobnosti, svojprávnosti a procesnej spôsobilosti. Podla lex societatis sa určuje vznik, existencia a zánik spoločnosti. D̆alej lex societatis upravuje aj vnútornú a vonkajšiu organizáciu, práva a povinnosti spoločníkov, prevod spoločenských práv, otázky spoločenskej zmluvy a stanov (napríklad o navýšení kapitálu), usporiadanie majetku a otázky zodpovednosti, obzvlášt' piercing the corporate veil, ${ }^{18}$ orgány a ich právne postavenie vo vnútorných a vonkajších vzt’ahoch, zodpovednost' členov výkonných orgánov, oprávnenie zastupovat', zmenu formy spoločnosti, premenu splynutím a rozdelenie spoločnosti. Rovnako otázky právneho nástupníctva, vrátane prípadnej neplatnosti tohto prechodu sa posudzujú podla lex societatis. ${ }^{19} \mathrm{Pod}$ vnútornou organizáciou sa rozumie postavenie orgánov vo vnútorných a vonkajších vzt’ahoch, obzvlášt' menovanie členov týchto orgánov, ich kompetencie a oprávnenie zastupovat' spoločnost', ${ }^{20}$ otázky zmeny spoločenskej zmluvy, zmeny kapitálu (peňažné a nepeňažné vklady, ručenie). ${ }^{21}$

Jedným z dôvodov zakladania kapitálových spoločností je vytvorenie takzvaného „firemného závoja“, ktorý oddel’uje majetok spoločníkov od majetku spoločnosti. Spoločníci tak môžu prostredníctvom svojej účasti v kapitálovej spoločnosti organizovat' podnikatel'skú činnost', s ktorou je pojmovo spojené podnikatel'ské riziko. Toto riziko nesie samotná spoločnost' a spoločníci ručia za prípadné záväzky spoločnosti len do výšky nesplatených vkladov. Splatením ich vkladu sa od záväzkov spoločnosti dištancujú. Aby však nedochádzalo k zneužívaniu tohoto „schovania sa za firemný závoj“

17 Nariadenie Európskeho parlamentu a Rady (EU) 1215/2012 zo dňa 12. decembra 2012, o príslušnosti a uznávaní a výkonu súdnych rozhodnutí v občianskych a obchodných veciach.

18 Rozhodnutie rakúskeho Najvyššieho súdu pod spisovou značkou 6 Ob 226/09t, dostupné na: https://www.ris.bka.gv.at/Dokument.wxe?Abfrage=Justiz\&Dokumentnummer=JJT_20100415 OGH0002_0060OB00226_09T0000_000 [14.1.2019].

19 Rozhodnutie rakúskeho Najvyššieho súdu zo dňa 11. augusta 2015, 4 Ob 30/15p. Dostupné na: https://www.ris.bka.gv.at/Dokument.wxe?Abfrage=Justiz\&Dokumentnummer=JJT_20150811 _OGH0002_0040OB00030_15P0000_000[14.1.2019].

20 Rozhodnutia rakúskeho Najvyššieho súdu zo dňa 14. júla 1993, 8 Ob 634/92, 23. marca 2007, 2 Ob 170/06y, 15. septembra 2010, 2 Ob 238/09b, OGH 11. októbra 1995, 3 Ob 64/95. Všetky dostupné na: https://www.ris.bka.gv.at/default.aspx [14. 1.2019].

21 Rozhodnutie rakúskeho Najvyššieho súdu zo dňa 25. marca 2014, 9 Ob 68/13k. 
k tomu, že spoločníci svojou nezodpovednost'ou privedú spoločnost' do insolvencie na úkor veritel'ov, existuje inštitút nazvaný ako ,piercing the corporate veil“ (d'alej len ako „piercing“), jedná sa o tzv. „prelomenie majetkovej samostatnosti právnickej osoby“. Vo výnimočných prípadoch tento inštitút umožňuje veritel’om sa obrátit’ nie na spoločnost', ale priamo na jej spoločníkov, poprípade manažérov a spravit' ich osobne zodpovednými za záväzky spoločnosti. 22

V rakúskom práve spoločností sa piercing posudzuje podl'a lex societatis, spadá tak pod osobný štatút spoločnosti. Podl'a rakúskeho Najvyššieho súdu však k tomu musí byt' splnená podmienka spočívajúca $\mathrm{v}$ tom, že možnost' ručenia a jeho rozsah vyplýva z formy spoločnosti, a nie napríklad zo zmluvy. ${ }^{23}$

Čo sa týka právnej úpravy firmy a názvu, tiež sa použije lex societatis. ${ }^{24}$

Rakúsky súd posudzoval rovnako prípad prevodu rakúskej spoločnosti s ručením obmedzeným na nemeckého jediného spoločníka, a posúdil, že rozhodným právom pre túto premenu bude rakúske právo. ${ }^{25}$ Rakúsky Najvyšší súd konštatoval, že premena prevzatím spoločnosti nezasahuje do organizačnej štruktúry hlavnej spoločnosti. Premena prevzatím uskutočňuje organizačný akt zanikajúcej spoločnosti. Nemecká spoločnost' premenou prevzatím získala nový majetok, v zásade sa jej to však organizačne nedotklo. Zasiahnutá bola viac rakúska spoločnost', ktorá týmto aktom zanikla, a preto sa použilo právo rakúske. $Z$ rovnakej myšlienky vychádza smernica Európskeho parlamentu a Rady (EU) 2017/1132 zo dňa 14. júna 2017 o niektorých aspektoch práva obchodných spoločností, ktorý upravuje cezhraničné premeny v článku 118 a nasledujúcich. ${ }^{26}$

Ako krátky exkurz je možné dodat', že osobný štatút spoločnosti má význam aj v kolíznej úprave povinnosti vedenia účtovníctva zahraničnej spoločnosti, ktorá bola založená v Európskej únii alebo Európskom. Hospodárskom priestore, ale ústrednú správu má v Rakúsku. Toto je významné najmä z daňového hladiska. Napríklad britská spoločnost' vo forme právnickej osoby Ltd. (Limited) má spoločenský štatút britské právo, ktoré bude zároveň aj účtovným štatútom. Anglické predpisy sa však v mnohom líšia od tých rakúskych, preto musí dochádzat' k prispôsobeniu vedenia účtovníctva pre rakúske daňové účely. Tak dochádza k stretávaniu zakladajúceho štatútu s účtovným štatútom. Európske právo následne túto úpravu harmonizovalo, a určilo ako rozhodujúci štatút právo štátu, kde bola spoločnost’ založená.

22 LOKAJÍČEK. J. Doktrína Piercing the Corporate Veil neboli prolomení majetkové samostatnosti právnické osoby a její možnosti v českém obchodním právu. Právní rozhledy. Praha: C. H. Beck, 2011, č. 12, s. 425 a násl.

23 Rozhodnutie rakúskeho Najvyššieho súdu zo dňa 7. novembra 1985, číslo 7 Ob 610/85. Dostupné na: https://rdb.manz.at/document/ris.just.JJT 19851107 OGH0002 0070OB00610 8500000000 [20. 1.2019].

24 Rozhodnutie rakúskeho Najvyššieho súdu zo dňa 9. augusta 2011, 17 Ob 6/11y, dostupné na: https://www.ris.bka.gv.at/Dokument.wxe?Abfrage=Justiz\&Dokumentnummer=JJT_20110809 OGH0002_0170OB00006_11Y0000_000[14.1.2019].

25 Rozhodnutie rakúskeho Najvyššieho súdu pod spisovou značkou 6 Ob 283/02i. Rozhodnutie je dostupné na: https://www.ris.bka.gv.at/Dokument.wxe?Abfrage=Justiz\&Dokumentnummer=JJT_20030320 OGH0002_0060OB00283_02I0000_000 [12.1.2019].

$26 \overline{\mathrm{V}}$ súčasnosti je už uverejnený návrh smernice, ktorý by mal túto smernicu novelizovat', jedná sa o návrh smernice Európskeho parlamentu a Rady, ktorou sa mení smernica (EU) 2017/1132, pokial' ide o cezhraničné premeny, fúze a rozdelenia COM/2018/241 final - 2018/0114 (COD). 


\subsection{LIMITY LEX SOCIETATIS}

Rozsah spoločenského štatútu sa taktiež nepriamo udáva z článku 1 ods. 2 písm. f) nariadenia Rím I a článku 1 ods. 2 písm. d) nariadenia Rím II. Podl'a týchto článkov sa tieto nariadenia nepoužijú na otázky týkajúce sa spoločností, právo spolčovací a otázky týkajúce sa právnických osôb, ako je vznik spoločnosti, právna osobnost' a svojprávnost', vnútorné stanovy a zánik spoločnosti, d’alej osobné ručenie spoločníkov a orgánov za záväzky spoločnosti, spolku alebo inej právnickej osoby. Tieto otázky spadajú pod spoločenských štatút. Tak napríklad otázka, či faktickému konatel'ovi náleží právo zastupovat' spoločnost', sa posudzuje podl'a rozhodného osobného štatútu. ${ }^{27}$

Od osobného štatútu je nutné odlišovat' deliktný štatút. Deliktná zodpovednost' právnickej osoby je kvôli úzkej súvislosti s právom na náhradu škody posudzované podl'a deliktného štatútu, konkrétne podl’a čl. 15 písm. a) nariadenia Rím II. To bude spravidla právo sídla, pretože škodný následok bude väčšinou nastávat' v mieste, kde vykonáva spoločnost' svoje aktivity. Pre firemné právo spoločnosti je ale už rozhodný osobný štatút spoločnosti. Zaujímavá je aj úprava prevodu podielu v spoločnosti. Pokial' sa jedná o úkon dispozičný, použije sa osobný štatút spoločnosti. Ak pôjde o úkon zaväzujúci, aplikuje sa lex causae, konkrétne nariadenia Rím I.

Pre otázky insolvenčného konania, napríklad žaloby veritel'ov na neplatnost' právnych jednaní, súkromnoprávna zodpovednost’ členov výkonného orgánu a spoločníkov za zmenšovanie insolvenčnej podstaty a priet'ahy v insolvenčnom konaní sa použije lex concursus. $^{28}$

\subsection{MODIFIKÁCIA RAKÚSKEHO LEX SOCIETATIS}

Ustanovenie $\S 10 I P R G$ však platí v úplnosti len vo vzt’ahu k tretím štátom. Vo vzt'ahu k členským štátom Európskej únie je v tomto ustanovení zakotvený princíp sídla modifikovaný základnými slobodami Európskej únie. To neplatí pre vzt’ahy s americkým prvkom, kedy sa prednostne aplikuje medzinárodná dvojstranná zmluva medzi Rakúskou spolkovou republikou a Spojenými štátmi.

V prípade, že spoločnost’ registrovaná v Rakúsku má svoje hlavné sídlo správy v tret’om štáte, ${ }^{29}$ otázka jej právnej osobnosti je závislá od toho, či daný tretí štát aplikuje zásadu sídla alebo inkorporácie. V prvom prípade dochádza k zmene osobného štatútu. Právna osobnost' môže byt' ohrozená ustanoveniami tretieho štátu. V opačnom prípade, dochádza k použitiu spätnému odkazu a k zmene štatútu nedochádza. Aplikuje sa rakúske korporačné právo.

Ak cudzia spoločnost', ktorá je registrovaná v tret’om štáte, premiestni sídlo svojej hlavnej správy do Rakúska, opät' sa aplikuje rakúske právo. Jedným z možných riešení by v takejto situácii bolo, že by sa vybrala najbližšia forma rakúskej obchodnej spoločnosti, čo plynie požiadavku numerus clausus foriem rakúskych obchodných spoločnos-

27 Ustanovenie $\S 10$ a 12 IPRG, rozhodnutie rakúskeho Najvyššieho súdu pod spisovou značkou 2 Ob 238/09 b.

28 EIDENMÜLLER. H. Gesellschaftsstatut und Insolvenzstatut. Rabels Zeitschrift (RabelsZ), 2006, vol. 70, s. 474, 493. Alebo: ADENSAMER. N. Ein neues Kollisionsrecht für Gesellschaften. Vien: Linde Verlag Ges.m.b.H., 2006, s. 201 a násl.

29 Zaujímavost'ou je, že sa na švajčiarske spoločnosti uplatní § 10 IPRG tak, ako na ostatné tretie štáty. 
tí. Kvôli nutnosti registrácie však taká subsumpcia nie je možná, a táto spoločnost’ nemá právnu osobnost', resp. musí byt' znovu založená.

Z kolízneho hladiska síce nehrá zmena zapísaného sídla žiadnu úlohu, podl’a väčšinového názoru, sa však musí u rakúskej spoločnosti zhodovat' so skutočným sídlom hlavnej správy. ${ }^{30}$

Ako inkorporačný princíp, tak aj teória sídla majú svoje výhody a nevýhody. Inkorporačný princíp dozaista lepšie odráža vôlu zakladatel'ov a taktiež podporuje princíp istoty. Na druhej strane so sebou prináša možnost' zvolit' si akýkol'vek právny poriadok zväššenie manipulačného priestoru, a to v neprospech veritel'ov, zamestnancov, budúcich akcionárov v mieste skutočného pôsobenia spoločnosti. Teória sídla tento manipulačný priestor razantne zmenšuje. Teória sídla však zabraňuje premiestneniu sídla do iného štátu či zapísanie zahraničnej pobočky do obchodného registru. Tak mnohé spoločnosti po premiestnení sídla stratia svoju právnu osobnost' a procesnú spôsobilost'.

Práve toto neuznávanie cudzích spoločností v Rakúsku bolo posudzované Súdnym dvorom Európskej únie (d’alej len ako SDEÚ), ${ }^{31}$ a to vo vzt'ahu k slobode usadzovania. Táto judikatúra značne zmenila výklad § $10 I P R G$. V zásade dnes platí, že prinajmenšom otázky právnej osobnosti a svojprávnosti sa posúdia podl’a práva členského štátu, podl'a ktorého spoločnost' vznikla. Je tomu tak, z niekol'kých dôvodov.

Sloboda usadzovania zakazuje obmedzenia usadzovania spoločností (primárna sloboda usadzovania), ako aj obmedzenia v zakladaní agentúr, pobočiek či dcérskych spoločností (sekundárna sloboda usadzovania). Všetky spoločnosti založené podla práva jedného z členských štátov, ktoré majú zapísané sídlo, ústrednú správu alebo sú usadené v rámci Európskej únie, sa môžu na túto slobodu odvolat'. Sloboda usadzovania sa vzt’ahuje aj na Európsky hospodársky priestor, teda na Island, Lichtenštajnsko a Nórsko.

$\mathrm{V}$ prípadoch, ked' dochádza k právnemu nástupníctvu na základe premeny, vyvstáva otázka ako tento prípad kvalifikovat'. Všetko nasvedčuje tomu, že sa aplikuje spoločenský štatút. Pobočky sa riadia vlastným osobným štatútom. V rámci Európskej únie a Európskeho hospodárskeho priestoru je inkorporačný štatút rozhodný pre posúdenie otázky právnej osobnosti pobočky. V prípade absencie právnej osobnosti u pobočky je rozhodným štatútom právo právnickej osoby alebo právneho útvaru, ktorému patria. ${ }^{32}$

Ako sme si ukázali, je nutné rozlišovat' právnické osoby z členských štátov a tie, ktoré sú z tretích štátov, a to práve z pohl'adu aplikácie európskeho práva. Spoločnost' založená podl'a práva niektorého z členských štátov existuje podl'a tohto práva, teda podl'a práva, ktoré je rozhodné pre jej založenie. ${ }^{33}$ Tento štát si sám stanoví podmienky pre založenie spoločnosti a taktiež si sám stanoví podmienky, za ktorých spoločnost' ostane spoločnost'ou pod ,patronátom“ tohto práva. ${ }^{34}$ Tým pádom ostáva

30 KALLS, S. - NOVOTNY, CH. - CHAUER. M. Österreichisches Gesellschaftsrecht. Wien: Manz, 2008. Rz 3/34. A dále: MITTERECKER, J. Grenzüberschreitende Sitzverlegungen. Wien: Verlag Österreich, 2015, s. 88 a násl.

31 Rozhodnutia SDEÚ Daily Mail, Centros, Überseering, Inspire Art, SEVIC Systems AG, Cartesio, Vale Epitesi Kft (spisové značky budú uvedené pri bližšom pojednaní o týchto rozhodnutiach).

32 Rozhodnutie rakúskeho Najvyššieho súdu pod spisovou značkou 8 Ob 221/74.

33 Tzv. teória založenia spoločnosti. Rozhodnutie SDEÚ C-81/87 vo veci Daily Mail.

34 Rozhodnutie SDEÚ C-210/06 vo veci Cartesio. 
na štátoch, či ponechajú spoločnosti právnu osobnost' v prípade prenesenie sídla do zahraničia, alebo nie. ${ }^{35,36}$

\subsection{EUROKONFORMNÝ VÝKLAD LEX SOCIETATIS}

V rozhodnutí Centros ${ }^{37}$ SDEÚ považoval za porušenie sekundárnej slobody usadzovania prípad, kedy došlo k odmietnutiu zapísania pobočky v jednom štáte, pričom spoločnost' bola zapísaná v inom štáte. Toto rozhodnutie potvrdil Súdy dvor aj v prípade Inspire Art. ${ }^{38}$

Tak Überseering, ako aj Inspire Art boli spoločnosti, ktorých reálne sídlo sa nezhodovalo so sídlom zapísaným (štatutárnym). Ich štatutárne sídlo bolo v inom členskom štáte, než ich reálne sídlo. Presadenie inkorporačného princípu spočívalo v skutočnosti, že SDEÚ judikoval, že prijímajúci členský štát, tj. členský štát kde mala spoločnost’ svoje reálne sídlo, je povinný uznat' právnu osobnost' tejto spoločnosti, ktorá ale plynie z právneho poriadku iného členského štátu, v ktorom je spoločnost' zapísaná. V druhom prípade SDEÚ nad to zakázal ukladat' štátu, kde má spoločnost' reálne sídlo, takejto spoločnosti povinnosti nad rámec tých, ktoré od nej požadovalo právo štátu, kde je spoločnost’ zapísaná. Premiestnenie skutočného sídla predstavuje realizáciu primárnej slobody usadzovania a preto je možné konštatovat', že využitie výhodnejších podmienok založenia spoločnosti v zahraničí nepredstavuje porušenie európskeho práva.

Z rohodnutí Centros, Inspire Art a Überseering ${ }^{39}$ vyplýva ,,princíp uznania spoločnosti“, ktorý má prednost' pred $\S 10 I P R G .{ }^{40} \mathrm{~V}$ tejto oblasti sa tak presadí inkorporační princíp. Podl'a rakúskeho Najvyššieho súdu ale nie je nutný celkový odklon princípu sídla zakotveného v $§ 10$ a $12 I P R G,{ }^{41}$ nakol'ko aj v prípade uplatnenia slobody usadzovania je možné aplikovat' kogentné ustanovenia rakúskeho práva, ako práva prijímajúceho štátu, ak sú dané nevyhnutné dôvody všeobecného záujmu. Materiálne normy štáty určeného podl'a $§ 10$ sa môžu d'alej aplikovat', ak to nijak nebráni slobode usadzovania, teda neupiera sa právna osobnost' spoločnosti, či sa neobmedzuje jej činnost'.

Britská „Limited“ sa tak v Rakúsku uzná za spoločnost' s právnou osobnost’ou a rovnako procesnou spôsobilost'ou. Z judikatúry sa neudáva, aký je presne lex societatis takejto osoby. Ako sa posúdi napríklad piercing the corporate veil? Vzhl'adom na tesné prepojenie ručenia spoločníkov s požiadavkami na založenie spoločnosti, priklonil sa

35 Tamtéž.

36 Toto tvrdenie rozhodnutie Daily Mail v zásade potvrdilo, korigovanie prišlo s rozhodnutím SDEÚ C-371/10 vo veci National Grid Indus. Rozhodnutím Cartesio sa situácia ustálila tak, že spoločnosti pri prenesení sídla musí byt' umožnená cezhraničná premena so zachovaním identity spoločnosti.

37 Rozhodnutie SDEÚ C-212/97 vo veci Centros.

38 Rozhodnutie SDEÚ C-167/01 vo veci Inspire Art.

39 Rozhodnutie SDEÚ C-208/00 vo veci Überseering.

40 Rozhodnutie rakúskeho Najvyššieho súdu zo dňa 29. apríla 2004 pod spisovou značkou 6 Ob 44/04w dostupné na: https:/www.ris.bka.gv.at/Dokument.wxe?Abfrage=Justiz\&Dokumentnummer=JJT_20040429 OGH0002_0060OB00044_04W0000_000 [14.1.2019].

41 Rozhodnutie rakúskeho Najvyššieho súdu zo dňa 16. marca 2011 pod spisovou značkou 6 Ob 67/10m, dostupné na: https://www.ris.bka.gv.at/Dokument.wxe?Abfrage=Justiz\&Dokumentnummer=JJT_20110316 _OGH0002_0060OB00067_10M0000_000 [14. 1.2019]. 
rakúsky Najvyšší súd k názoru, že by to malo byt' posúdené podl'a britského práva. To odpovedá dnes už ustálenej judikatúre tohto súdu. ${ }^{42}$

Sloboda usadzovania sa uplatní v súlade s rozhodnutím SEVIC Systems ${ }^{43}$ aj v prípade cezhraničných splynutí spoločností. Odmietnutie zápisu nástupnickej spoločnosti je tak značné obmedzené. Od roku 2007 je táto matéria upravená smernicou o cezhraničných fúziách spoločností. V rozhodnutí Vale Epitesi $\mathrm{Kft}^{44}$ SDEÚ ale vyslovil, že ak národné právo vôbec neupravuje možnost' cezhraničnej premeny, tak to nie je v rozpore s európskym právom. Hlavné pravidlo tohoto rozhodnutia by sa však dalo formulovat' tak, že právna úprava premien spoločností nesmie byt' k európskym spoločnostiam diskriminačná a v rozporu so slobodou usadzovania. Tieto dva rozhodnutia však nemajú priamy vplyv na § 10 IPRG. Platí tak, že vždy ked' má dôjst' k premene zahraničnej spoločnosti na rakúsku, musí dôjst' k splneniu požiadaviek rakúskeho korporačného práva na tú ktorú konkrétnu spoločnost', a to ešte pred zápisom spoločnosti do obchodného registru. ${ }^{45}$ Potrebná je aj zmena skutočného správneho sídla, nielen sídla zapísaného.

Princípy európskeho práva týkajúce sa uznania spoločnosti a inkorporačný princíp vedú spoločne k tomu, že sa spoločnosti zakladajú v štáte, ktorý má výhodnú hmotnoprávnu úpravu korporačného práva a zároveň si toto právo skrz inkorporačný princíp vezmú so sebou do štátu, kde vykonávajú svoju činnost'. Ako reakcia na túto skutočnost' vznikla v Rakúsku spoločnost's ručením obmedzeným s nižším štartovacím kapitálom (tzv. ,GmbH Light").

Ako reakcia na judikatúru SDEÚ sa v Nemecku už vyše jedno desat'ročie uvažuje o zakotvení jednotného naviazania základných pravidiel judikovaných SDEÚ na teóriu sídla (teoreticky v kombinácii s imperatívnymi normami). Ciel’om je priniest’ žiadanú právnu istotu a prehl'adnost' do právnych pomerov. V roku 2008 nemecké ministerstvo spravodlivosti vypracovalo legislatívne návrhy riešenia najzásadnejších problémov, na ktoré príspevok poukazuje, žiaduce by však bolo, aby odpovedajúcu právnu úpravu vypracovala Európska komisia.

Právo Európskej únie, a z neho prameniace zásady a slobody ako napríklad zásada zákazu diskriminácie či sloboda usadzovania (články 49 a 54 Zmluvy o fungovaní Európskej únie), vrátane judikatúry SDEÚ, tak majú vel'ký vplyv na vývoj rakúskeho medzinárodného práva spoločností a rovnako aj rakúskeho obchodného práva.

Na základe predostretej analýzy je možné konštatovat' dva hlavné poznatky. Za prvé, musí byt' rozlišované medzi vecami vzt'ahujúcimi sa k tretím štátom, kde sa uplatní neobmedzene $\S 10$ rakúskeho zákona o medzinárodnom práve súkromnom (princíp sídla) a medzi vecami vzt’ahujúcimi sa k európskym štátom, kde sa uplatní princíp sídla modifikovaný o zásadu uznania spoločnosti podl’a zásady inkorporácie. Za druhé,

42 Rozhodnutie rakúskeho Najvyššieho súdu zo dňa 13. septembra 2007 pod spisovou značkou 6 Ob 146/06y, dostupné na: https://www.ris.bka.gv.at/Dokument.wxe?Abfrage=Justiz\&Dokumentnummer=JJT_20070913 OGH0002_0060OB00146_06Y0000_000 [14. 1. 2019].

43 Rozhodnutie SDEÚ vo veci C-411/03 SEVIC Systems AG.

44 Rozhodnutie SDEÚ vo veci C-378/10 VALE Építési kft.

45 Rozhodnutia rakúskeho Najvyššieho súdu, prvé zo dňa 10. apríla 2014 so spisovou značkou 6 Ob 224/13d, druhé zo dňa 15. mája 2014 so spisovou značkou 6 Ob 223/13g, dostupné na: https://www.ris.bka.gv.at /default.aspx [14. 1. 2019]. 
hmotné a kolízne medzinárodné právo spoločnosti nesmú byt’ v rozpore so slobodou usadzovania.

Preto musia pravidlá medzinárodného práva spoločnosti prejst' takzvaným testom proporcionality, ktorý pozostáva zo štyroch elementov: nesmie sa jednat' o diskriminačné opatrenie, nesmie byt' v rozpore $s$ verejným záujmom, musí viest' $k$ zamýšlanému ciel'u a vzhl'adom na zamýšl'aný ciel' je primerané. ${ }^{46}$

\section{LEX SOCIETATIS V MEDZINÁRODNOM KONCERNE}

Napriek značnému hospodárskemu významu koncernov v Európskej únii existuje, a to nielen v českom práve, významná priepast’ medzi ekonomickou realitou a jej právnou reflexiou. Koncernové právo je označenie pre právo podnikatel'ských zoskupení, názov nesie podla vrcholnej formy ${ }^{47,48}$ a upravuje právne pomery vznikajúce pri ovplyvnení, ovládaní či v rámci koncernu. Koncernové podnikatel'ské zoskupenie skrýva radu výhod, ale taktiež nevýhod. Tieto nevýhody v prípade insolvencie môžu významne zasiahnut' veritel'ov dcérskej korporácie. Musíme mat' totižto na pamäti, že záujem koncernu má prednost' pred záujmom jednotlivých korporácií.

$\mathrm{Na}$ tomto mieste sa je vhodné pozriet' na právnu úpravu koncernového podnikatel'ského zoskupenia z pohl'adu rakúskeho obchodného práva a na to, aké prostriedky koncernového práva pre ochranu veritel'ov upravuje. Koncernové právo ako čast' práva spoločností sa zaoberá otázkami práva spoločností, ktoré sa zúčastňujú rôznych podnikatel'ských zoskupení, pričom sú spojené jednotným vedením alebo inými vzt’ahmi. ${ }^{49}$ V Rakúsku neexistuje kodifikované koncernové právo spoločností. Práve preto existuje množstvo sporných otázok týkajúcich sa koncernov. Existuje však zvláštna právna úprava účtovníctva pre koncerny. $\mathrm{V}$ rakúskom zákone o spoločnosti s ručením obmedzeným ${ }^{50}$ a rovnako $\mathrm{v}$ zákone o akciovej spoločnosti ${ }^{51}$ je niekol'ko ustanovení, ktoré viažu skutkovú podstatu na existenciu koncernu. Podmienkou pre existenciu koncernu v rakúskom práve nie je zmluva, ktorá by zväzovala jednotlivé spoločnosti. Zmluvné koncerny sú v Rakúsku výnimkou. Základom zmluvného koncernu je tzv. „ovládacia zmluva““.52 Spolčenie spoločností sa dá odvodit’ aj z objektívnych okolností. Vel'mi často sa dá koncern dovodit' $v$ prípadoch, ked' sa jedna spoločnost' podiel'a na účasti v inej spoločnosti. Ovplyvňovat' druhé spoločnosti sa dá však aj inými prostriedkami. Tak môže mat' jedna spoločnost' napríklad $80 \%$ akcií druhej spoločnosti. Alebo môže mat' jedna spoločnost' to isté personálne zastúpenie v orgánoch ako druhá spoločnost'. Spoločnosti môžu byt' aj hospodársky závislé. Spolčenie spoločností prináša množstvo problémov. Obzvlášt' môžu byt' zasiahnutí menšinoví spoločníci, ktorých vplyv na dcérsku spoločnost' je prakticky potlačený. Zákon reguluje prípad účasti v kótovanej

46 VERSCHRAEGEN, B. op. cit. sub 10, s. 185.

47 Pozri tiež napr.: ČERNÁ, S. Koncernové právo v Německu, Evropské unii a České republice. Praha: C. H. Beck, 1999.

48 ČERNÁ, S. In: ČERNÁ, S. - ŠTENGLOVÁ, I. - PELIKÁNOVÁ, I. a kol. Právo obchodnich korporací. Praha: Wolters Kluwer, 2015, s. 204.

49 RATKA, T. - RAUTER, R. - VÖLKL, C. Unternehmens- und Gesellschaftsrecht. Wien: Manz. 3. Auflage, 2017, s. 68.

50 Zákon zo dňa 6. marca 1906, o spoločnostiach s ručením obmedzeným (GmbH-Gesetz) č. 58/1906.

51 Zákon zo dňa 1. januára 1966, o akciových spoločnostiach (AktG), č. 24/1985.

52 RATKA, T. - RAUTER, R. - VÖLKL, C. op. cit. sub 42, s. 69. 
akciovej spoločnosti, kedy zákon stavuje povinne možnost' squeezeout-u. Účast' spoločnosti v koncernu sa týka aj postavenia veritel’ov tejto spoločnosti. Platí zákaz vrátenia vkladov a okrem toho prichádza v úvahu aj ručenie materskej spoločnosti pre prípad jej škodlivého ovplyvňovania. ${ }^{53}$

Koncern nedisponuje právnou osobnost’ou. Ide o „faktum“. Je zložený zo spoločností, ktoré disponujú právnou osobnost'ou. Rakúske právo nesuspenduje kogentné ustanovenia práva spoločností pre prípad koncernu. Pre koncern je príznačné ako jednotné vedenie, tak závislost' jednej spoločnosti na druhej. Koncern je v rakúskom práve definovaný v ustanovení $§ 115$ ods. 1 zákona o spoločnosti s ručením obmedzeným a v $\S 15$ ods. 1 zákona o akciovej spoločnosti v zásade zhodne, a to ako zoskupenie právne samostatných podnikov pod jednotným vedením. Jednotné vedenie je tak hlavným znakom existencie koncernu a musí byt' fakticky uskutočňované. Potrebná miera jednotného vedenia nie je presne určená, v zásade je možné však konštatovat', že stačí základná koordinácia najdôležitejších otázok podnikovej politiky. ${ }^{54}$ Dôležité je, aby sa jednotné vedenie zameriavalo na finančné otázky, hlavne investície. ${ }^{55}$ Ďalej zákon stanoví, že koncern vznikol tiež v prípade, kedy je jeden podnik závislý od druhého podniku. Zákon hovorí o ovládajúcom vplyvu. V tomto prípade sa má za to, že je jednotné vedenie predpokladom tejto závislosti. Ide tak o obrátenie dôkazného bremena. Spojené podniky upravuje taktiež § 189a a § 244 rakúskeho obchodného zákonníku, ${ }^{56}$ tieto ustanovenia obsahujú tzv. „Control-Tatbestände“.

Zmluvy medzi koncernovými spoločnost’ami obsahujú ustanovenia, ktoré sa odchyl’ujú od stanov a zaväzujú spoločnosti. Týkajú sa základov fungovania spoločností a silne interferujú do stanov spoločností. Formálne však stanovy nemenia. Pre uzatvorenie takýchto zmlúv sa vyžaduje súhlas najvyššieho orgánu. Typy zmlúv medzi spoločnost’ami sú ovládacia zmluva, zmluva o prevodu ziskov, zmluva o pachtu podniku (termín je z oblasti českého práva) a zmluva o vedení podniku. Úprava je obsiahnutá v § 238 akciového zákona, neobsahuje však ovládaciu zmluvu. Nutné je tak upozornit', že v Rakúsku je ovládacia zmluva mimo právnu úpravu a jej zákonnost' je sporná. ${ }^{57}$

V medzinárodných koncernoch je rozhodný spoločenský štatút dcérskej spoločnosti ako podriadenej spoločnosti. Ten sa použije aj pre otázky prepichnutia firemného závoja, ktorý sa bude týkat' materskej spoločnosti, a to za dlhy jej podriadenej spoločnosti. ${ }^{58}$

\section{LEX SOCIETATIS V PROCESNOM MEDZINÁRODNOM PROCESNOM PRÁVE SPOLOČNOSTÍ}

Obecne podl'a článku 4 ods. 1 nariadenia Brusel I bis je daná právomoc súdov na základe obvyklého pobytu osoby. Podl’a článku 63 tohto nariadenia sa určuje obvyklý pobyt spoločností a právnických osôb podla miesta, kde sa nachádza zapísané

53 Tamtéž, s. 69.

54 Tamtéž, s. 71.

55 Tamtéž, s. 71-72.

56 Podnikatel'ský zákonník zo dňa 1. januára 2007 (UGB), č. 72/2007.

57 RATKA, T. - RAUTER, R. - VÖLKL, C. op. cit. sub 42, s. 75.

58 Rozhodnutie rakúskeho Najvyššieho súdu pod spisovou značkou 1 Ob 541/81. Dostupné na: https:// www.ris.bka.gv.at/Dokument.wxe?Abfrage=Justiz\&Dokumentnummer=JJT_19810617_OGH0002_001 0OB00541_8100000_000. 
sídlo, hlavná správa alebo hlavné usadenie. Hovorí sa o mieste skutočného výkonu obchodnej činnosti. Ak sa tieto miesta nezhodujú, má žalobca na výber. Výnimky predstavuje článok 24 písm. 2 nariadenia, ktoré pre určitý okruh prípadov stanovuje výlučnú právomoc. Pre tieto veci sa použije kritérium sídla podla článku $10 I P R G .^{59}$ Jedná sa napríklad o žaloby na platnost' uznesení orgánov spoločnosti, žaloby na platnost', ničotnost' či zrušenie spoločnosti. ${ }^{60}$ Jedná sa len o kontradiktórne jednania. Naopak žaloby veritel'ov proti spoločníkom na ručenie či žaloby spoločníkov o podiel na zisku sem nespadajú. 61

\section{ROZHODNÉ PRÁVO V INSOLVENČNOM KONANÍ - LEX SOCIETATIS VS. LEX CONCURSUS}

\subsection{VÝZNAM INSOLVENČNÉHO KONANIA S MEDZINÁRODNÝM PRVKOM NA VZOSTUPE}

S fenoménmi globalizácie a europeizácie súvisí rovnako narastajúci počet nadnárodných spoločností, ktoré majú svoj majetok umiestený často na území niekol'kých štátov. Taktiež s ohl'adom na narastanie medzinárodného obchodu si dnes prakticky už nie je možné predstavit’ insolvenčné konanie bez medzinárodného prvku. V tejto časti príspevku sa zameriame na úpravu riešenia ich úpadku v priebehu medzinárodného insolvenčného konania.

V medzinárodnom insolvenčnom konaní sa riešia otázky, ktoré obsahujú medzinárodný prvok. Kolízia právnych poriadkov vzniká, ak má insolvenčné konanie dopad na územie viacerých štátov. To sú prípady, ked’ má dlžník domicil, obchodné aktivity alebo majetok v niekol'kých štátoch. ${ }^{62}$

Na nasledujúcich niekol'ko riadkoch si kladieme za ciel' predostriet' stručnú právnu analýzu situácie, kedy sa dostane do insolvenčného konania rakúska spoločnost' zúčastňujúca sa koncernového podnikatel'ského zoskupenia, pričom sa bude jednat' o medzinárodný koncern, ale centrum ekonomických a hospodárskych záujmov tohto koncernu bude $\mathrm{v}$ Rakúsku, a preto rozhodným právom, dopadajúcim aj na zahraničné spoločnosti $\mathrm{v}$ koncerne, bude právo rakúske.

Úpadok je v živote korporácie javom so značnými hospodárskymi a právnymi následkami. Jedná sa o situáciu, kedy má korporácia problémy plnit’ svoje záväzky voči veritel'om, závod nie je schopný života a nastupujú aj právne následky a činnost' insolvenčného správcu, ktorej účelom je speňaženie aktív, ktorá v závode ešte zostala. Dá sa tvrdit', že členovia korporácie majú postavenie reziduálnych vlastníkov, pričom s vlastnícky podiel zahrňuje okrem napríklad práva účasti na riadení korporácie taktiež

59 MITTERECKER, J. Grenzüberschreitende Sitzverlegungen. Wien: Verlag Österreich, 2015, s. 175.

60 RAUSCHER, T. (Hrsg.). Europäisches Zivilprozess- und Kollisionsrecht: EuZPR/EuIPR: Kommentar. 4. Auflage. Köln: Otto Schmidt, 2016, s. 70.

61 LURGER, B. - MELCHER, M. Handbuch Internationales Privatrecht mit Hinweisen auf das Internationale Zivilverfahrensrecht. Wien: Verlag Österreich, 2017, s. 413 a násl.

62 POLÁČEK, B. Právo mezinárodního obchodu. Praha: Wolters Kluwer, 2017, s. 308. 
reziduálny, teda zvyškový, nárok na jej majetok a reziduálne riziko straty. ${ }^{63}$ Ked' sa dostane korporácia do úpadku, zvyškové nároky spoločníkov korporácie sa vyprázdňujú. Reziduálne vlastníctvo prechádza de facto na veritel'ov. ${ }^{64}$ Dochádza taktiež v zmene riadenia spoločnosti, teda výkonu obchodného vedenia korporácie. Spoločníci korporácie $\mathrm{v}$ úpadku pri vedomí obmedzeného ručenia sú častejšie ochotní sa podielat' na rizikových obchodoch, ktoré sa vyznačujú často len marginálnou šancou na úspech či až zúfalost'ou. Nie je neobvyklá dokonca trestná činnost' spoločníkov, ktorá spočíva v nezákonnom prevode majetku z korporácie. Právo na tieto situácie samozrejme reaguje a zbavuje členov výkonného orgánu riadenia spoločnosti a výkon obchodného vedenia a zastupovanie spoločnosti prenáša na insolvenčného správcu. Insolvenčný správca vystupuje ako skutočný manažér spoločnosti, ktorý vedie obchody, ktoré budú ako $\mathrm{v}$ prospech spoločnosti, tak aj $\mathrm{v}$ prospech veritel'ov.

\subsection{INSOLVENČNÉ KONANIE ZAHÁJENÉ PRED RAKÚSKYM SÚDOM}

Insolvenčné právo zbavuje veritel’a práva individuálneho postupu pri vymáhaní jeho pohl'adávky voči dlžníkovi a nahradzuje ho postupom kolektívnym, ktorým je insolvenčné konanie. ${ }^{65}$ Bežnou situáciou v koncerne je, že jednotlivé spoločnosti majú vzájomné dlhy a pohl'adávky. Jedným z veritel'ov tak môže byt' práve spoločnost' tvoriaca s dlžníkom koncern. Pokial' sa niektorá zo spoločností z koncernu dostane do insolvenčného konania, ostatné spoločnosti z koncernu majú vo vzt’ahu k pohl'adávkam voči dlžníkovi postavenia veritel'a.

V pomere k členským štátom Európskej únie, s výnimkou Dánska, sa bude aplikovat' nariadenie o insolvenčnom konaní, ${ }^{66}$ pričom insolvenčné konanie s európskym prvkom a jeho účinky okrem tohoto nariadenia budú riadit’ ustanoveniami právneho poriadku toho členského štátu Európskej únie, na ktoré nariadenie o insolvenčnom konaní odkazuje. Európsky prvok nariadenie nedefinuje. Najčastejšie sa však pod ním rozumie situácia, kedy sú hlavné záujmy dlžníka sústredené v niektorom z členských štátov Európskej únie a súčasne aspoň jeden $z$ veritel'ov alebo čast' majetkovej podstaty sa nachádza $\mathrm{v}$ niektorom $\mathrm{z}$ iných členských štátov.

Nariadenie o insolvenčnom konaní obsahuje unifikované kolízne normy a nadväzuje tak na nariadenie Brusel I bis, ktoré v článku 1 ods. 2 písm. b) latentne konštatuje, že sa nevzt'ahuje na insolvenčné konanie a podobné konanie.

Rakúske insolvenčné právo stavuje, že ak existuje predpoklad zahájenia insolvenčného konania (v slovenskej terminológii začiatok konania), majú členovia výkonného orgánu povinnost' podat' návrh na zahájenie insolvenčného konania. Tí nebudú v oneskorení, ak zčnú sanačné konanie s vlastnou správou, to neplatí, ak je spoločnost' v platobnej neschopnosti alebo zadížení viac než 60 dní. Výnimku predstavuje prírodná katastrofa, kedy je doba stanovená na 120 dní. Od roku 2013 má túto povinnost’aj spo-

63 FAMA, E. F. - JENSEN, M. C. Agency Problems and Residual Claims. The Journal of Law \& Economics, 1983, vol. 26, issue 2, s. 327-349.

64 JACKSON, T. H. The logic and limits of bankruptcy law. Washington: Beard Books, 1986, s. 101.

65 RICHTER, T. Insolvenční právo. 2., doplněné a upravené vydání. Praha. Wolters Kluwer, 2017, s. 208.

66 Nariadenie Európskeho parlamentu a Rady (EU) 2015/848 zo dňa 20. mája 2015 o insolvenčním konaní (v texte d'alej len ako ,nariadenie o insolvenčnom konaní"). 
ločník, a to v prípade, ak spoločnost' nemá členov výkonného orgánu, alebo disponuje nadpolovičnou väčšinou základného kapitálu. U kapitálových spoločností sú stanovené alternatívne dva dôvody zahájenia insolvenčného konania: platobná neschopnost' (§ 66 rakúskeho insolvenčného poriadku ${ }^{67}$ a zadíženie. Insolvenčné konanie sa zahájí, ak má spoločnost' $\mathrm{k}$ dispozícii finančné prostriedky, ktoré by pokryli náklady konania (cca 4 tis. eur). Insolvenčné konanie sa delí na sanačné a konkurzné. Sanačné konanie pritom môže byt's vlastnou správou alebo bez vlastnej správny. Ak sa ukáže, že sanačné konanie neprinieslo záchranu spoločnosti, zmení sa v konkurz spoločnosti.

Ak je daná právomoc rakúskych súdov pre zahájenie insolvenčného konania podl’a nariadenia o insolvenčnom konaní, vzt’ahuje sa toto nariadenie aj na dlžníkov majetok v d’alšom členskom štáte Európskej únie. Insolvenčný správca menovaný príslušným súdom v hlavnom insolvenčnom konaní môže vykonávat' všetky právomoci, ktoré mu zveruje právo štátu, ktorý konanie zahájil, v inom členskom štáte. Môže napríklad premiestňovat' majetok z územia členského štátu, v ktorom sa nachádza. ${ }^{68}$ Pokial' sa insolvenčné konanie týka dvoch alebo viac členov skupiny spoločností, spolupracuje insolvenčný správca menovaný v konaní proti členovi takej skupiny s ktorýmkol'vek iným insolvenčným správcom menovaným $\mathrm{v}$ konaní proti inému členovi tej istej skupiny v rozsahu, v akom je taká spolupráca vhodná pre ul'ahčenie účelného vedenia konania a nie je nezlučitel’ná s pravidlami, ktoré sa na ňu vzt’ahujú a zároveň nevedie $\mathrm{k}$ strete záujmov (článok 56 ods. 1 nariadenia).

Na insolvenčné konanie a jeho účinky sa rozhodné právo určuje prednostne podl'a nariadenia o insolvenčnom konaní, teda na základe kolízneho kritéria, ktorým podl’a tohoto nariadenia je miesto zahájenia konania.

Podl'a článku 1 nariadenia o insolvenčnom konaní sa toto nariadenie vzt'ahuje na verejné kolektívne konania, ktoré sú založené na práve upravujúcom úpadok a v ktorých, za účelom záchrany, úpravy dlhu, reorganizácie alebo likvidácie je dlžník úplne alebo čiastočne zbavený dispozičných oprávnení k svojmu majetku a je menovaný insolvenčný správca, je majetok a záležitosti dlžníka pod kontrolou či dohl'adom súdu alebo je súdom alebo na základe zákona priznané dočasné prerušenie konania na vymáhanie individuálnych nárokov s ciel’om umožnit' jednanie medzi dlžníkom a jeho veritel'mi, za predpokladu, že dané konanie, v ktorého rámci bolo prerušenie priznané, zaistí vhodné opatrenia na ochranu veritel'ov.

Súdy členského štátu, na území ktorého sú sústredené hlavné záujmy dlžníka (center of main interests $\left.{ }^{69}\right)$, sú príslušné k zahájeniu insolvenčného konania, stanoví tak článok 3 predmetného nariadenia. Hovoríme o hlavnom insolvenčnom konaní. Miestom, kde sú sústredené hlavné záujmy dlžníka, je miesto, z ktorého dlžník svoje záujmy pravidelne spravuje a ktoré je zistitel'né tretími osobami. V prípade právnickej osoby sa za

67 Zákon o insolvenčnom konaní zo dňa 11. decembra 1914 (Insolvenzordnung - IO), č. 337/1914.

68 V súlade s článkom 33 insolvenčného nariadenia výhrada verejného poriadku predstavuje jediný dôvod pre odmietnutie uznania insolvenčného konania zahájeného v inom členskom štáte alebo výkon rozhodnutí učinených v súvislosti s takým konaním.

69 Na tomto mieste nepovažujeme za nevyhnutné inštitút centra hlavných zájmov dlžníka bližšie vykladat', čitatel’a je však možné odkázat' na zásadné rozhodnutia SDEÚ vo Eurofood, rozhodnutie SDEÚ zo dňa 2. mája 2006 vo veci C-341/06 a d'alej Interedil, rozhodnutie SDEÚ zo dňa 20. októbra 2011 vo veci C-396/09. 
miesto, kde sú sústredené jej hlavné záujmy, považuje sídlo, ak sa nepreukáže opak. Táto domnienka platí len $\mathrm{v}$ prípade, ak $\mathrm{v}$ období troch mesiacov pred podaním návrhu na zahájenie insolvenčného konania nedošlo k presunu sídla do iného členského štátu. V prípade osoby samostatne zarábajúcej sa za miesto, kde sú sústredené jej hlavné záujmy, považuje hlavné miesto jej podnikania, ak sa nepreukáže opak. Táto domnienka platí len v prípade, že v období troch mesiacov pred podaním návrhu na zahájenie insolvenčného konania nedošlo $\mathrm{k}$ presunu hlavného miesta podnikania tejto fyzickej osoby do iného členského štátu. Ciel'om takejto úpravy je zabraňovat' praxi označovanej ako forum shopping, ktoré súvisí s prevádzaním majetku, eventuálne aj súdnych konaní, z jedného členského štátu Európskej únie do druhého za účelom získania výhodnejšieho „sudišta“" na úkor veritel’ov. Nariadenie obsahuje relatívne presné pravidlá pre koncernové insolvenčné konania, ked' v piatej kapitole upravuje vedenie insolvenčného konania proti členom skupín spoločností, ktorými nariadenie rozumie materskú spoločnost' a všetky dcérske spoločnosti. Pre takéto zoskupenie je daná možnost' postupu zvláštnym koordinovaným konaním, kedy vstupuje do funkcie takzvaný koordinátor, ktorý navrhuje plán celej skupiny a integrovaný prístup k riešeniu úpadku jej členov.

Okrem inštitútu hlavného insolvenčného konania, nariadenie o insolvenčnom konaní pracuje taktiež s inštitútom vedl'ajšieho insolvenčného konania. Stanoví, že pokial' sú hlavné záujmy dlžníka sústredené na území niektorého členského štátu, sú súdy iného členského štátu príslušné $\mathrm{k}$ zahájeniu insolvenčného konania proti tomuto dlžníkovi, ale len vtedy, ak má prevádzku na území tohto iného členského štátu. Účinky vedl’ajšieho insolvenčného konania sú obmedzené na majetok, ktorý sa nachádza na území tohto členského štátu.

Podla článku 7 ods. 1 nariadenia o insolvencii je rozhodným právom pre insolvenčné konanie a jeho účinky právo toho členského štátu, na ktorého území bolo insolvenčné konanie zahájené. Hovoríme o zásade lex fori concursus. Jedná sa o právo štátu, v ktorom má dlžník sústredené svoje hlavné záujmy. Právo štátu, ktorý konanie zahájil, určuje podmienky pre zahájenie tohto konania, jeho vedenia a skončenia. Podl'a odseku 2 predmetného článku určuje hlavne to, proti ktorým typom dlžníkov môže byt' insolvenčné konanie zahájené, ktorý majetok tvorí súčast' majetkovej podstaty, oprávnenia dlžníka a insolvenčného správcu a tomu podobne, ale napríklad aj pravidlá týkajúce sa neplatnosti, odporovatel'nosti alebo neúčinnosti právnych jednaní poškodzujúcich spoločný záujem veritel’ov. V prípade, že insolvenčné konanie zaháji rakúsky súd, bude pre insolvenčné konanie rozhodné právo rakúske, to znamená hlavne rakúsky zákon o insolvencii. ${ }^{70}$

Z iného uhlu pohl'adu sa dá tiež tvrdit', že článok 7 obsahuje kolízne ustanovenia pre cezhraničnú insolvenciu v Európskej únii. Strany si však môžu želat' pre určité transakcie zvolit' právo, a to vtedy, ked' kolízne normy nariadenia neposkytujú dostatočnú

$70 \mathrm{~V}$ insolvenčnom nariadení sú obsiahnuté ustanovenia, ktoré stanovujú odlišne rozhodné právo pre niektoré účinky uznania insolvenčného konania. Napríklad zmluvy týkajúce sa nehnutel’ností sa riadia výhradne právom členského štátu, na ktorého území sa nehnutel'nost’ nachádza. Pracovné zmluvy sa riadia výhradne právom členského štátu, ktorým sa riadi daná pracovná zmluva. Pri jednaní poškodzujúcom všetkých veritel’ov sa právo štátu, ktorý konanie zahájil, nepoužije, ak osoba, ktorá má z toho prospech, preukáže, že je pre toto jednanie rozhodné právo iného členského štátu než štátu, ktorý konanie zahájil, a že právo uvedeného členského štátu neumožňuje v danom prípade toto jednanie žiadnym spôsobom napadnút'. 
istotu svojej aplikácie. Rovnako platí pre transakcie, ktoré podliehajú právu tretieho štátu, kde bolo insolvenčné konanie zahájené, že tu naráža nariadenie o insolvenčnom konaní svoje medze.

\subsection{STRET LEX FORI CONCURSUS A LEX SOCIETATIS V INSOLVENČNOM KONANÍ}

Hranice insolvenčného štatútu sú jednak stanovené pozitívne, teda stanovené právnou normou upravujúcou lex fori concursus, a zároveň sú vymedzené aj negatívne, a to osobným štatútom spoločnosti a obligačným štatútom.

Tak napríklad, vznik práva a jeho obsah sa líši od jeho postavenia v insolvenčnom konaní. ${ }^{71}$ Kolízne normy môžu určit' rozhodné právo pre zmluvu. Toto hmotné rozhodné právo potom určuje jej platnost' a účinnost'. Súd v insolvenčnom konaní používa vlastné kolízne normy pre posúdenie týchto otázok. Lex fori concursus teda neurčí otázky vzniku pohl'adávky. Právo rozhodné pre insolvenčné konanie naopak určuje postavenie pohl'adávok a ich druhy. Činí tak s ohl'adom na ich úpravu v pôvodnom štáte pohl'adávky a snaží sa nájst' $\mathrm{k}$ cudzím pohl'adávkam ekvivalent tak, aby postavenie takejto pohl’adávky sa podobalo jej postavenie $\mathrm{v}$ štáte, podl'a práva ktorého sa posudzujú otázky jej platnosti a obsahu.

Väčší problém než skíbit' $\mathrm{v}$ insolvenčnom konaní lex fori concursus a lex causae predstavuje otázka vzt’ahu lex fori concursus a lex societatis, teda spoločenského štatútu osoby, resp. spoločnosti. Rovnako ako lex fori concursus neučuje vznik práva a jeho obsah, nevzt'ahuje sa ani na otázky existencie subjektov insolvenčného konania. Osobný štatút vychádza z národných úprav medzinárodného práva súkromného, pričom je na vol'be konkrétneho štátu, či určí ako kolízne kritérium inkorporáciu alebo miesto reálneho výkonu obchodného vedenia spoločnosti.

Použitel'nost' lex fori concursus na cudziu spoločnost' je naviazaná na úsudok o tom, či sa posudzovaná otázka bude vzt'ahovat' $\mathrm{k}$ priebehu insolvencie alebo osobnému štatútu spoločnosti. Ak sa rozhodneme, že otázka spadá do osobného štatútu spoločnosti, bude rozhodné právo štátu, podl’a práva ktorého spoločnost' vznikla alebo kde má svoju ústrednú správu. Ak usúdime, že sa jedná o vec týkajúcu sa insolvenčného konania, použijeme právo štátu, súd ktorého insolvenčné konanie zahájil. Je pri tom nerozhodné či pôjde o normy zákona o insolvencii alebo zákona o obchodných korporáciách či iného právneho predpisu. Právneho poriadku sa užije ako celku tak, ako by sa v štáte jeho platnosti vyriešila otázka spadajúca do rozsahu kolíznej normy.

Je vel'mi zložité jasne vymedzit’ rozsah aplikácie jednotlivých hraničných určovatel'ov. Prakticky vo všetkých prípadoch, kedy sa nebude zhodovat' rozhodné právo určené na základe jedného a následne druhého z týchto hraničných určovatel'ov, budú tieto otázky relevantné. Napríklad tieto otázky sú sporné: zodpovednost' členov výkonného orgánu, zodpovednost' spoločníkov koncernovej spoločnosti, ${ }^{72}$ subordinácia príjmov spoločníkov, piercing of the corporate veil, automatická extenzia insolvencie spoločnosti na jej spoločníkov (aj takú úpravu niektoré štáty obsahujú), vplyv reštruk-

71 Porovnaj UNCITRAL Legislative Guide on Insolvency Law. New York: United Nations, 2005, s. 68.

72 Napríklad vo veciach piercing the corporate veil alebo vo vzt'ahu k žiadostiam o vrátenie platieb z úverov akcionárov. 
turalizácie či reorganizácie na právny režim právnickej osoby či napríklad modifikácia organizačnej, finančnej alebo kapitálovej štruktúry. Nariadenie o insolvenčnom konaní nestanovuje pevnú hranicu medzi lex fori concursus a lex societatis. V týchto otázkach sa dá hovorit' v akomsi zmysle o rozštiepenom štatúte, ktorý sa v priebehu insolvenčného konania môže objavit'.

Táto problematika je o to poznanie dôležitejšia, že korporačné právo, ktoré sa vzt'ahuje na insolvenciu a insolvenčné právo vzt’ahujúce sa na korporácie sa naprieč Európskou úniou vel'mi odlišujú. Ani v jednej z týchto oblastí sa v dohl'adnej dobe nepredpokladá unifikácia. Je vhodné na tomto mieste vyslovit' apel na európskeho zákonodarca, aby sa $\mathrm{v}$ budúcnosti týmito otázkami zaoberal.

Vel'ký význam v tejto otázke má článok 6 ods. 1 a článok 32 ods. 1 nariadenia o insolvencii a výklad slovného spojenia ,action which derived directly from the insolvency proceedings and is closely linked with them". V insolvenčnom konaní je často vel'mi dôležité určit' rozhodné právo pre porušenie povinností člena výkonného orgánu a taktiež členov vrcholného orgánu. $K$ tomu je však nutné správne interpretovat' práve článok 6 ods. 1 nariadenia o insolvencii. Tieto skutkové podstaty by bolo možné hodnotit' ako otázky lex societatis, lex fori concursus či lex loci delicti. Správna kvalifikácia a podradenie pod správnu kolíznu normu bude mat' za následok aplikáciu konkrétneho právneho poriadku. $V$ tomto prípade podl’a rakúskej literatúry bude aplikovatel’né nariadenie o insolvenčnom konaní, to znamená, že sa použije právo štátu, ktorý insolvenčné konanie zahájil. ${ }^{73}$ Podl'a lex fori concursus sa posúdi aj platnost' právnych jednaní, ktorým sa úmyselne zhoršilo postavenie veritel'ov. Široká vecná pôsobnost' nariadenia o insolvencii, ktorého lex incorporationis upozad'uje lex societatis a zároveň nariadenie Brusel I B bis, je založená na rozsiahlej judikatúre SDEÚ. V rozhodnutí Gourdain a Nadler ${ }^{74}$ SDEÚ judikoval, že sa nariadenia použije vždy, pokial' je daný úzky a bezprostredný vzt’ah k insolvenčnému konaniu. Práve taký úzky vzt’ah je daný u žalobách na platnost' právnych jednaní, rozhodnutia Seagon a Deko Marty Belgium NV. ${ }^{75}$ Rovnako bol posúdený prevod podielu insolvenčného dlžníka správcom podstaty na zahraničnú spoločnost' (SCT Industri AB/Alpenblume $\mathrm{AB}^{76}$ ).

Ked' sa pozrieme na rozhodnutie SDEÚ vo veci Kornhaas, ${ }^{77}$ SDEÚ sa v ňom odvoláva na predošlé rozhodnutie vo veci $\mathrm{H}$ proti $\mathrm{H}$. K. ${ }^{78}$ kedy posudzoval ustanovenie národného práva, konkrétne $\S 64$ ods. 2 nemeckého zákona o spoločnosti s ručením obmedzeným (GmbHG), v ktorom sa stanovuje, že člen výkonného orgánu spoločnosti $\mathrm{v}$ úpadku musí navrátit' platby, ktoré učinil menom spoločnosti potom ako sa dostala do úpadku, nepatrí do rozsahu spoločenského štatusu, ale jedná sa o úpravu insolvenčného konania. Na základe toho SDEÚ určil rozhodné právo na základe lex fori concursus, teda právo štátu, súd ktorého insolvenčné konanie zahájil.

\footnotetext{
VERSCHRAEGEN, B. op. cit. sub 10, s. 197.

4 Rozhodnutie SDEÚ zo dňa 22. februára 1979 vo věci C-133/78 Gourdain v Nadler.

75 Rozhodnutie SDEÚ zo dňa 12. februára 2009 vo veci C-339/07 Christopher Seagon, konajúci ako správca konkurznej podstaty Frick Teppichboden Supermärkte GmbH proti Deko Marty Belgium NV.

76 Rozhodnutie SDEÚ zo dňa 2. júla 2009 vo veci C-111/08 - SCT Industri.

77 Rozhodnutie SDEÚ vo veci C 594/14, Kornhaas, ECLI:EU:C:2015:806.

78 Rozhodnutie SDEÚ zo dňa 4. decembra vo veci C 295/13, H v. H.K.
} 
Argumentácia súdu sa opiera o skutočnost', že toto ustanovenie spadá pod rozsah nariadenia, pretože prispieva k dosiahnutiu ciel'a, ktorý je ten istý vo všetkých insolvenčných konaniach a síce predchádzanie akémukol’vek zmenšovaniu majetku pred zahájením insolvenčného konania tak, aby nároky všetkých veritel'ov mohli byt' uspokojené v čo najväčšom rozsahu a za rovnakých podmienok.

Pre zhrnutie sa dá tvrdit', že SDEÚ dáva v značnom rozsahu prednost' lex fori concursus, ked’ stačí i trocha významný „odkaz“ na insolvenčné konanie. Čitatel'a je tak dobré upozornit', že súdy s najväčšou pravdepodobnost'ou budú aplikovat' lex fori concursus na všetky otázky, vychádzajúce priamo z insolvenčného konania, a s ktorým sú spojené.

\section{ZÁVERY}

Z pohl'adu medzinárodného práva spoločností je Rakúsko tradičným kontinentálnym typom právnej kultúry, v ktorom sa uplatňuje princíp sídla ako rozhodné kritérium pre určenie rozhodného práva obchodnej spoločnosti. Pre právo spoločností je zásadné ustanovenie $\S 10$ rakúskeho zákona o medzinárodnom práve súkromnom, ktoré je, čo sa týka rozsahu, koncipované obdobne ako český $\S 30$ zákona o medzinárodnom práve súkromnom. Rakúsky lex societatis sa však potýka s omnoho väčším množstvom výkladových problémov než jeho český ,,protejšok“. Je tomu tak z dôvodu intereferencie s právom Európskej únie, ktoré zakotvuje pre medzinárodné právo spoločnosti vel'mi významnú slobodu usadzovania spoločností. Práve na základe argumentácie slobodou usadzovania vznikla rozsiahla judikatúra SDEÚ, ktorá rakúsky lex societatis postavený na princípe sídla do značnej miery modifikuje.

1. Prvým záverom tohto príspevku je tak poznatok, že v systéme rakúskeho práva sa odlišne zachádza so spoločnost’ami, ktoré majú sídlo v niektorom z členských štátov Európskej únie, a spoločnost'ami z tretích štátov.

2. Z druhého záveru príspevku plynie zistenie, že súčasný vývoj v Rakúsku nenasvedčuje tomu, že by sa rakúsky zákonodarca hodlal princípu sídla vzdat', a to napriek tomu, že SDEÚ konštantne judikuje v prospech inkorporačného princípu ako princípu, ktorý je, na rozdiel od princípu sídla, schopný podporit’ fungovanie jednotného trhu v Európskej únii.

3. Ako vyplýva z tretieho záveru tohto príspevku, medzinárodná insolvencia je doménou medzinárodných koncernov. To by samo o sebe nebolo žiadnym problematickým zistením, pokial' by sme sa nedopracovali k tomu, že v insolvenčnom konaní sa aplikuje nielen lex fori concursus, ale taktiež lex societatis. A práve lex societatis nás odkazuje na koncernové právo, ktorého unifikácia na úrovni Európskej únie je zatial' v nedohl'adne.

4. Štvrtým záverom tohto príspevku je poznatok, že SDEÚ dáva vo svojej judikatúre zjavný signál, že do budúcna bude uprednostňovat' lex fori concursus pred lex societatis.

V porovnaní s českou úpravou rozhodného práva pre právnické osoby je právna úprava v rakúskom zákone o medzinárodnom práve súkromnom stručnejšia. V usta- 
novení § 10 tohoto zákona nájdeme lakonické vyjadrenie, že lex societatis právnickej osoby alebo iného združenia osôb či majetkového usporiadania s právnou osobnost'ou je právo štátu, v ktorom má právnická osoba skutočné sídlo svojej hlavnej správy. Na toto ustanovenie nadväzuje $\S 12$, v ktorom sa stanoví, že právna osobnost' a svojprávnost' sa posudzuje podl'a lex societatis. Zákon je tak stručný a rozsah osobného štatútu spoločnosti určuje hlavne judikatúra. Na základe uskutočnenej analýzy je možné konštatovat', že rakúsky Najvyšší súd zahrňuje pod rozsah osobného štatútu obchodnú firmu, vnútorné pomery, pomery medzi právnickou osobou a jej spoločníkmi a vzájomné pomery spoločníkov alebo členov, ručenie spoločníkov alebo členov za záväzky právnickej osoby a taktiež oprávnenie zastupovat' právnickú osobu či jej zánik. Rozsah je tak vel’mi blízky českému $§ 30$ ods. 1 zákona o medzinárodnom práve súkromnom, ktorý upravuje osobný štatút podl’a českého práva. Rozdiely v rozsahu osobného štatútu, teda vymedzenie otázok ktoré spadajú pod lex societatis, sú tak medzi českou a rakúskou právnickou úpravou len vel'mi malé a spočívajú $\mathrm{v}$ dodatočných podmienkach, ktoré stanovil rakúsky súd $\mathrm{k}$ tomu, aby určitá otázka skutočne spadala do rozsahu osobného štatútu.

V čom sa rakúsky osobný štatút lišsi od českého lex societatis je hraničný ukazatel', podla ktorého sa rozhodné právo pre právnickú osobu stanoví. České medzinárodné právo súkromné vychádza pri určovaní rozhodného práva z inkorporačného princípu, rakúske medzinárodné právo z materiálneho pojatia skutočného sídla. Proti rýdzemu princípu sídla sa však niekol'ko krát vymedzil SDEÚ, ktorý v uplatňovaní tohoto princípu na spoločnosti z členských štátov Európskej únie uvidel porušenie slobody usadzovania. Rozhodnutia SDEÚ sa stali príčinou odlišného výkladu rakúskeho osobného štatútu vo vzt’ahu k spoločnostiam so sídlom v Európskej únii a so sídlom mimo Európsku úniu.

JUDr. Dominik Králik

Právnická fakulta Univerzity Karlovy

kralikd@prf.cuni.cz 